\title{
The Relationship between Multiple Intelligences and Iranian EFL Learners' Level of L2 Lexical Knowledge: The Case of Gender
}

\author{
Reza Biria \\ English Department, Islamic Azad University, Khorasgan (Isfahan) Branch, \\ PO box 81595-158, Isfahan, Iran \\ E-mail: r_biria@yahoo.com \\ Abbas Mehrabi Boshrabadi (corresponding author) \\ English Department, Islamic Azad University, Khorasgan (Isfahan) Branch, \\ PO box 81595-158, Isfahan, Iran \\ E-mail: abbas.mehrabi596@gmail.com \\ Elham Nikbakht \\ English Department, Islamic Azad University, Khorasgan (Isfahan) Branch, \\ PO box 81595-158, Isfahan, Iran \\ E-mail:elhamnikbakht@ymail.com
}

Doi:10.7575/aiac.alls.v.5n.3p.9

Received: 01/04/2014

URL: http://dx.doi.org/10.7575/aiac.alls.v.5n.3p.9

Accepted: 03/05/2014

\begin{abstract}
Human cognitive competence represents individuals' subconscious knowledge of abilities, talents, and mental skills collectively called "multiple intelligences (MIs)", which play a pivotal role in facilitating human learning. Thus, the main objective of the present study was to determine the magnitude of the relationship existing between multiple intelligences and Iranian EFL learners' level of second language (L2) lexical knowledge on one hand and the partializing impact of gender on the other. For this purpose, from the population of the senior undergraduate students majoring in translation at Islamic Azad University, Khorasgan (Isfahan) Branch, Isfahan, Iran, a sample of 88 students, 24 males and 64 females, were randomly selected. First, Mckenzie's (1999) MIs Inventory was administered to specify the size of individual types of intelligences in each learner's MIs composite. Then, the learners were provided with Nation's (2001) receptive level test a week later to gauge their level of L2 lexical knowledge. The findings revealed that the scores on MIs inventory correlated positively with those of L2 lexical knowledge. Alternatively, different types of intelligences served as useful predictors for estimating the quality of learners' vocabulary knowledge. Finally, it was found out that gender did indeed have a different effect regarding the learners' vocabulary knowledge.
\end{abstract}

Keywords: Gender, Iranian EFL learners, L2 lexical knowledge, Multiple intelligences

\section{Introduction}

We are now living in an era called the age of individualism in which values and differences are highly respected. In fact, scientists have started to take a fresh look at the cognitive and affective variables governing human beings. This shift of attention has left its influence on the way education is viewed and practiced. Evidently, individual differences now occupy an important position in any debate regarding the teaching/learning process. Unsurprisingly, the professional literature is replete with the terms and phrases whose aim is to shed light on the mysterious nature of the concepts distinguishing one person from another (Lefrancois, 1991; Crozier, 1997). This renovation of interest can be attributed to the advent of a new intelligence theory called Multiple Intelligences (MIs). Based on this construct, Gardner (1983) defines the human's intelligence as a composite of different abilities and aptitudes providing a resource by which all individuals can be assessed and evaluated.

Accordingly, Gardner (1983), in his book Frames of Mind: The Theory of Multiple Intelligences, classified human's intelligence into nine distinctive categories; namely, Musical, Verbal/Linguistic, Logical/Mathematical, Spatial, Interpersonal, Intrapersonal, Natural, Bodily Kinesthetic, and Existential intelligence. As Gardner puts it, Musical Intelligence is the ability to think in music and rhythm, to play instruments, or to sign a song. We often employ this type of intelligence to alleviate stress, but it may also be used to think and learn a given language and its components such as vocabulary or accent. Alternatively, Verbal/Linguistic Intelligence is related to the capacity to speak, read, write, or learn languages. In fact, people with linguistic intelligence are intrinsically interested in teaching and/or explaining things to others. The next category is the Logical or Mathematical Intelligence, which can be described as the ability to solve problems and meet new challenges. This type of intelligence is associated with scientific thinking such as 
measuring the perimeter of the earth or predicting when an area will be hit by an earthquake. In other words, this ability is used to detect patterns, reason deductively, and think logically. Still another component of human intelligence is the Spatial Intelligence involving visualization of things or ideas, through which we can retain memories for a longer period of time. Differently stated, it enables us to grasp meanings better when they are traced with visual images. For example, Nelson (2006) suggests that students synthesize and create new meanings when they combine visual images and texts in, for example, digital storytelling activities. The Interpersonal Intelligence is another type of intelligence which is most frequently used by foreign language teachers since it is expressed in daily interactions in which people tend to engage in cooperation, agreement and disagreement with others. In such encounters, the interactants are often engaged in empathizing and sympathizing with others, leading and organizing groups, and working as a team member. Kagan (2000) points that these skills can be activated by cooperative learning structures. Similarly, the Intrapersonal Intelligence allows us to be independent and self-reflective. As Lazear (1999) maintains, intrapersonal intelligence activates the knowledge about and awareness of the internal aspects of the self such as knowledge about feelings, thinking processes, self-reflection, and etc. The examples of this type of intelligence are studying and performing homework in isolation. Additionally, the Natural Intelligence enables individuals to recognize, categorize, and make use of specific environmental features. The other component of human intelligence, Bodily-kinesthetic Intelligence, requires physical movements such as shoveling snow, painting pictures, dancing to music, or performing sports. As a matter of fact, it activates the ability to use the body to express feelings or desires. As an illustration, the Total Physical Approach in language teaching relies heavily on the use of bodily-kinesthetic intelligence. Finally, the Existential Intelligence refers to a person's ability to look inside when interacting with other people. The people, who are highly existentially intelligent, are expressive and regarded as experts in evaluating themselves.

Considering the qualities of individuals' intelligences, Gardner (1983) firmly asserts that all human beings enjoy some capacity in all types of intelligences or strengths and are capable of improving each of them to an appropriate level of competency so much so no two individuals have them in the same exact configuration. In fact, individuals are specialized only in one area of intelligences more than the others, and as a result, they would learn differently.

The application of MIs theory has been examined within the area of education and widely embraced by educators imposing numerous adaptations on it in a wide range of educational settings. By utilizing the MIs theory, teachers, who have somehow discovered the students' intellectual points of strength and weakness in the classroom, would be able to plan the lessons based on the learners' learning styles and intelligences. Accordingly, to improve the quality of education, teachers and policymakers can first assess the students' intelligence profiles and then design the teaching/learning activities with respect to the learners' needs. In this regard, Arnold and Fonseca (2004) affirm that if societies need to experience a significant advance in their educational system, the curriculum developers as well as teachers should recognize that the students in classrooms are not the same, rather, they have greatly different learning intelligence profiles.

As English language teaching plays an important role in educational context in Iran, a number of empirical studies have been conducted on the effect multiple intelligences might have on the teachers' and/or learners' success in EFL educational contexts. A summary of the related literature concerning the function of MIs is provided in Table 1.

Table1. A summary of some studies conducted on the role of MIs in EFL pedagogical context

\begin{tabular}{|c|c|c|c|}
\hline Author(s)/Year & $\begin{array}{c}\text { Participants and } \\
\text { Materials }\end{array}$ & $\begin{array}{l}\text { Objective of } \\
\text { Study }\end{array}$ & $\begin{array}{l}\text { Results and } \\
\text { Findings }\end{array}$ \\
\hline Mahdavi (2007) & $\begin{array}{l}\text { providing } 155 \text { senior EFL } \\
\text { students with TOEFL/IELTS } \\
\text { listening test and a MIDAS } \\
\text { questionnaire }\end{array}$ & $\begin{array}{l}\text { to investigate the role } \\
\text { of MIs on students' } \\
\text { listening proficiency }\end{array}$ & $\begin{array}{l}\text { spatial and musical } \\
\text { intelligences affected } \\
\text { TOEFL listening } \\
\text { scores significantly }\end{array}$ \\
\hline $\begin{array}{l}\text { Pishghadam\& } \\
\text { Moafian (2008) }\end{array}$ & $\begin{array}{l}\text { the Persian version of MIDAS } \\
\text { questionnaire was given to } 92 \\
\text { Iranian EFL teachers ( } 50 \\
\text { females and } 42 \text { males) }\end{array}$ & $\begin{array}{l}\text { to examine the role of } \\
\text { MIs on Iranian EFL } \\
\text { teachers' success in } \\
\text { teaching language }\end{array}$ & $\begin{array}{l}\text { a positive relationship } \\
\text { between teachers' } \\
\text { success and their } \\
\text { verbal, interpersonal, } \\
\text { musical intelligences }\end{array}$ \\
\hline Razmjoo (2008) & $\begin{array}{l}278 \mathrm{PhD} \text { candidates received } \\
\text { a questionnaire and a language } \\
\text { proficiency test }\end{array}$ & $\begin{array}{l}\text { to see whether each or a } \\
\text { combination of } \\
\text { intelligences are predictor } \\
\text { of language proficiency }\end{array}$ & $\begin{array}{l}\text { none of the intellige- } \\
\text { nces types could } \\
\text { predict the language } \\
\text { proficiency }\end{array}$ \\
\hline Sharifi (2008) & $\begin{array}{l}\text { a MIs questionnaire and a } \\
\text { researcher-developed } \\
\text { demographic questionnaire }\end{array}$ & $\begin{array}{l}\text { to find the relationship } \\
\text { between MIs and lesson } \\
\text { subject scores of }\end{array}$ & $\begin{array}{l}\text { female students were } \\
\text { superior to males in } \\
\text { intrapersonal intelli- }\end{array}$ \\
\hline
\end{tabular}


used for 120 high school

students majoring in

technical fields students with different

genders gence while males

performed better in

terms of spatial

intelligence

\begin{tabular}{ll}
\hline Motallebzadeh\& & 98 EFL learners who filled \\
Manouchehri (2009) & out the MIDAS questionnaire
\end{tabular}

to investigate the relation-

ship between MIs Iranian learners IELTS reading

test scores except for the logical

intelligence, there

was no significant

relation between MIs

and reading scores

\begin{tabular}{llll}
\hline BemaniNaeini\& & a TOEFL listening test and a & to explore the relationship & no significant relation \\
Pandian (2010) & questionnaire was provided & between MIs and listening & was found between \\
for 60 university students & proficiency & students' intelligence \\
& majoring in TEFL & & $\begin{array}{l}\text { and their listening } \\
\text { test scores }\end{array}$ \\
\hline
\end{tabular}

a. MIDAS stands for Multiple Intelligences Developmental Assessment Scale

Likewise, a number of researchers in other cultures have also made an attempt to explore the predictive nature of MIs in EFL educational settings. What follows is a summary of the most salient projects accomplished in this regard.

Focusing on the relevance of MIs to Computer Assisted Language Learning (CALL) instruction, Kim (2009) conducted a study in which 39 junior and senior female students majoring in English language and literature were provided with a TOEIC (Test Of English for International Communication) serving as a pretest. Consequently, a Korean MIs inventory questionnaire translated into English was given to the participants. To operationalize the CALL variable, the researcher divided the class time based on the types of intelligences-that is, $40 \%$ for verbal/linguistic intelligence, $40 \%$ for both spatial and intrapersonal intelligences, and $20 \%$ was devoted to the logical/mathematical and interpersonal intelligences. However, the other types of intelligences were not considered in this study. At the end of the experiment, the Kim supplied the participants with another TOEIC listening test along with the same MIs inventory questionnaire to see whether they had improved in their general listening comprehension proficiency. The results revealed that the mean scores of all types of MIs showed an improvement following the CALL instruction, but to different degrees. In fact, for three types of MIs under investigation; namely, spatial, linguistic, and logical/mathematical, the improvement of students' scores reached its highest percentage. By contrast, the next two types of intelligences, viz, interpersonal and intrapersonal, the correlation ratios between the students' listening scores before and after the CALL instruction were extremely low or even negative.

Following Kim's (2009) study, in 2010, Bakic-Miric also examined the theoretical and practical application of the MIs theory in the EFL classes. She aimed to investigate and monitor students' performances and improvements in learning English. To this end, a lecture plan for 80 fresh students of Pharmacy was displayed on OTC counselling during three consecutive phases. The first phase considered some activities in the classroom practicing verbal/linguistic intelligence. In the second phase, several tasks such as discussing and reporting similarities and differences among drawings were accomplished to operationalize the visual/spatial, interpersonal, and logical intelligences. Finally, the third phase included lectures whose aim was to activate the students' language abilities as well as the eight intelligences. Thus, the teacher monitored and worked on all intelligences in the class. Ultimately, it was concluded that the implementation of the MIs theory in EFL classes had a positive effect on both teaching and learning English language and enhanced students' interests towards learning the language.

Within the EFL pedagogical context, vocabulary acquisition process has also been considered as one of the most significant aspects that need to be investigated regarding the application of MIs theory. Indubitably, the knowledge of lexical items is clearly the core of language ability and the basic foundation of language learning process. Supporting this claim, Beglar and Hunt (2005) maintain that vocabulary acquisition would be considered the principal component in the successful foreign language learning. Similarly, Morgan and Rinvolucri (2004) state that vocabulary is the cornerstone in learning a second or foreign language due to the fact that it can lead to successful communication. As such, it would be essential to give thoughtful consideration to different strategies in order to learn the lexical items of a given language.

Furthermore, it is truly interesting for instructors to see what makes some of the students have a greater knowledge of vocabulary compared to others. Surprisingly, being a knowledgeable student does not necessarily mean possessing a large repertoire of vocabulary items. Still another interesting topic for instructors is to see what is the relationship existing between students' different types of intelligences and their vocabulary knowledge. Despite the significance of the matter, however, few studies (e.g., Skourdi\&Rahimi, 2010; Javanmard, 2012; Panahi, 2012) have been conducted to investigate the relationship between MIs theory and its impact on the students' level of L2 lexical knowledge. 
In this regard, in 2010, Skourdi and Rahimi investigated the possible role emotional and linguistic intelligences might play concerning university students' success in learning lexical items. For this purpose, the researchers employed three types of relevant instruments; namely, a revised version of the Nation's (2001) Word Level Test in order to estimate the vocabulary level of participants, a Linguistic Intelligence Questionnaire that was part of the Gardner's nine domains test on MIs, and Schutte's Self Report Emotional Intelligence Test. The findings illustrated that there was a positive relationship between emotional and linguistic intelligences and the participants' vocabulary knowledge. Moreover, it was found out that linguistic intelligence was a better predictor of vocabulary learning compared to emotional intelligence. In the same vein, Panahi (2012) also conducted a research project in order to explore the impact of spatial intelligence- based instruction on the vocabulary performance of EFL learners. Using a spatial intelligence questionnaire developed by Christison (1998) along with a pretest and a posttest, the researcher concluded that the learners with high and moderate levels of spatial intelligence, who enjoyed a picture-based instruction, performed better compared to the other group that was instructed non- pictorially.

Karimi, Pourdana, and Sayyedi (2012) also carried out an investigation on the predictive power of MIs on vocabulary testing in EFL context. The participants of the study were 130 Iranian EFL undergraduate students. Michigan English Language Assessment Battery (MELAB) as a standard test of vocabulary, and the Multiple Intelligences Developmental Assessment Scale's (MIDAS) questionnaire were two instruments used in the study. Having analyzed the results, the researchers concluded that, generally, there was a relationship between EFL learners' multiple intelligences profiles and their performances on the language tests. Accordingly, it was concluded that MIs and EFL learners' vocabulary assessment correlated positively.

Another important consideration, which has been the focus of this study, is the relationship between gender and MIs of specific learners. The main objective was to find out whether or not there was any significant difference between students' intelligence profiles and their genders. In this respect, Reis (1998) maintains that earlier studies on gender differences among gifted students have indicated that males outperform females in mathematics and science. According to Reis, the main reason that some girls do not succeed in mathematics is not any lack of ability or effort; it is simply that girls are not expected to succeed in these areas. Adolescent female students, on the other hand, revealed that they had a higher ability in language arts compared to males. These gender stereotypes are universal and similar findings of parental attitudes towards these stereotypes have been reported. (Tirri, 2002)

Tirri and Nokelainen (2007) presented the latest version of the Multiple Intelligences Profiling Questionnaire (MIPQ) that was based on the Gardner's (2006) MIs theory. The results of the correlational analysis between gender, age, and MIPQ scales revealed that males in the preadolescent sample possessed a higher level of logical/mathematical intelligence than females. The finding was adequately in line with the earlier studies concerning gender differences among gifted students. It was also found that the difference between the spiritual sensitivity of the males and that of the females was not statistically significant. In addition, focusing on the relationship between gender and MIs, Loori (2005) conducted a study on 90 EFL learners and found out that males rated higher in terms of logical/mathematical intelligence. On the other hand, based on the findings of his study, Razmjoo (2008) concluded that the frequency of the utility of intrapersonal intelligence by females was higher than that of males, whereas there was no difference between male and female participants regarding the role of different types of intelligences and participants' language success.

As mentioned earlier, individual words and phrases are the building blocks of communication and, as such, vocabulary acquisition process is claimed to be one of the main aspects in learning a foreign language. However, the way lexical items of a given language is presented has always been a controversial issue among the practitioners of the field, and as a result, there has been a lack of a unified approach in this connection. Accordingly, it is crucial to observe various related strategies in teaching or learning vocabulary successfully. Considering this fact, Javanmard (2012) explicitly asserts that personal differences play an important role in performing numerous linguistic tasks. He further argues that the participants' performances on vocabulary tests can be attributed not only to their intelligence performances, but also to other individual factors such as the styles and strategies the learners may employ to learn lexical items or take vocabulary tests.

On the basis of the above, the present study set out to explore the relationship between EFL learners' MIs and their level of lexical knowledge. Moreover, an attempt was made to specify the type of intelligence that is a better predictor of vocabulary size of EFL learners. Besides, the effect of gender on vocabulary learning process was analyzed considering the students' MIs. Therefore, the following research questions were formulated:

1. Is there any relationship between EFL learners' multiple intelligences and their level of L2 lexical knowledge?

2. What type of the intelligence profile is a better predictor of the vocabulary size of EFL learners?

3. Is there any significant difference between males and females in terms of their level of L2 lexical knowledge?

4. Is there any significant difference between males and females regarding the types of intelligence profiles?

\section{Materials and Method}

\subsection{Participants}

From the population of university senior undergraduate students, majoring in translation at Islamic Azad University, Khorasgan (Isfahan) Branch, Isfahan, Iran, a sample of 88 students (64 females and 24 males), aged between 20 and 25, were randomly selected. 


\subsection{Instruments}

There were two main instruments used in the study; namely, Nation's (2001) Receptive Level Test (NRLT) and the McKenzie's (1999) Multiple Intelligences Inventory (MMII). The first instrument, the NRLT, was utilized to measure the participants' vocabulary size. The internal consistency of the test was estimated based on the Cronbach's Alpha, which was 0.90 . The validity of the instrument was measured based on specialists' opinions. The NRLT consists of three levels, viz, 2000, 3000, and 5000-word levels. The difficulty level of the test items will increase proportionately as the number of word levels increases. For instance, the 2000-word level contains the easiest items compared to 3000 and 5000 -word levels. The test comprised of a total of 30 items, 10 for each level, and the participants had to answer the questions within a period of 15 minutes.

The other instrument used in the study was the MMII. To make sure that the participants are not confused and understand the semantic import of items on the inventory, the Persian version of the items was also available. In fact, the logic behind using the Persian version of the MMII was to assist the Limited English Proficiency (LEP) students. The MIs inventory is comprised of 90 items using a five-point Likert scale (Gardner, 1999). Each part consists of 10 statements, and the participants were told to answer the items on the inventory within 15 minutes.

\subsection{Procedures}

The major objective of the present study was to explore the differential influence of MIs on L2 lexical knowledge of male and female Iranian EFL learners. To this end, two different sets of tests, i.e., Nation's (2001) receptive level test and McKenzie's (1999) MIs inventory together with its Persian version were administered to the participants in two different sessions. The participants were then briefed on the items for the sake of clarity. Finally, the relationship between the English vocabulary test and learners' MIs scores was calculated. Then, the Pearson Product Moment Correlation was employed to estimate the correlation between the participants' vocabulary size and their MIs scores. Moreover, in order to determine the type of MI that was a better predictor of the EFL learners' level of L2 vocabulary knowledge, a Multiple Regression Analysis was also conducted. Besides, an Independent-Sample $t$-test was run to unravel the difference between males and females language learners as far as their knowledge of vocabulary is concerned. Finally, the Multivariate Analysis of variance was utilized to determine the possible difference existing between male and female students' MIs scores.

\section{Results and Discussion}

Based on the research questions, the following hypotheses were formulated:

- EFL learners' MIs scores do not correlate with their level of L2 lexical knowledge.

- None of the MIs is a better predictor of the vocabulary knowledge of EFL learners.

- There is no significant difference between male and female students in terms of their level of L2 lexical knowledge.

- There is no significant difference between male and female students regarding the types of intelligence profiles.

Considering the first research hypothesis, the Pearson Correlation was used to estimate the putative relationship existing between learners' size of vocabulary and their MIs scores. The preliminary analyses were accomplished to ensure that there has been no violation of the assumptions of normality, linearity, and homoscedasticity. As Table 2 illustrates, there exists a very small positive correlation between the two variables $(\mathrm{r}=.05, \mathrm{n}=88)$, indicating nearly no significant relationship existing between learners' level of L2 lexical knowledge and their MIs scores. Accordingly, the first null hypothesis would be confirmed.

Table 2. Pearson correlation between vocabulary knowledge and multiple intelligences scores

\begin{tabular}{|c|c|c|c|}
\hline & & Vocab & MIs Scores \\
\hline & Pearson Correlation & 1 & .051 \\
\hline \multirow[t]{2}{*}{ Vocab } & Sig. (2-tailed) & & .637 \\
\hline & $\mathrm{N}$ & 88 & 88 \\
\hline \multirow{3}{*}{ MIs Scores } & Pearson Correlation & .051 & 1 \\
\hline & Sig. (2-tailed) & 637 & \\
\hline & $\mathrm{N}$ & 88 & 88 \\
\hline
\end{tabular}

This finding is apparently not in line with the findings of the research conducted by Karimi, Pourdana, and Sayyedi (2012) on the predictive power of MIs on vocabulary testing in EFL context. Based on their findings, the researchers inferred that MIs and EFL learners' language component assessment correlated positively. Similarly, Panahi (2012) discovered that there was a significant relationship between spatial intelligence and students' learning of lexical items. In fact, unlike the learners with a low spatial intelligence, those learners who enjoyed a high or moderate level of spatial 
intelligence performed better on their vocabulary test once they were provided with the picture-based materials. However, Javanmard (2012), investigating the possible role MIs might play on the Iranian EFL learners' vocabulary test performance, found out that the higher a specific intelligence, the lower the vocabulary test score will be; and that the only type of intelligence that correlated positively to vocabulary test scores was bodily kinaesthetic intelligence. Interestingly, his finding is somehow consistent with the results of the present study.

The second research hypothesis predicted the type of MI that was a better predictor of the EFL learners' level of L2 lexical knowledge. A Multiple Regression Analysis was thus run to see whether there was any statistically significant difference between the variables. According to Table 3, the model fails to reach a statistical significant difference $(\mathrm{P}=$ $.74>0.05)$.

Table 3. Multiple regressions: statistical significance of the results

\begin{tabular}{llccccc}
\hline \multicolumn{1}{l}{ Model } & Sum of Squares & df & Mean Square & F & Sig \\
\hline & Regression & 1550.860 & 9 & 172.318 & .662 & .740 \\
1 & Residual & 20296.004 & 78 & 260.205 & & \\
\hline
\end{tabular}

Nonetheless, it would be informative to look at the following table to see which of the variables, if any, included in the model contributes more to the prediction of the dependent variable, i.e., learners' level of L2 lexical knowledge.

As can be seen in Table 4, the largest value belongs to the Linguistic Intelligence (LI $=.19$ ). As such, linguistic intelligence makes a unique contribution to teaching lexical items. However, the difference is not statistically significant $(\mathrm{p}=.180>0.05)$. Following the linguistic intelligence, the next largest value is related to the Naturalistic Intelligence $(\mathrm{NI}=.16)$. It is clearly observed that the predictive power of other MIs is decremented by $\mathrm{EI}=.11, \mathrm{IntraI}=.10, \mathrm{BKI}=$ $.07, \mathrm{LMI}=.059, \mathrm{VSI}=.053$, InterI $=.03, \mathrm{MI}=.02$, respectively.

Table4. Predictive power of MIs variables for vocabulary knowledge

\begin{tabular}{|c|c|c|c|c|c|c|c|c|c|c|}
\hline \multirow[t]{3}{*}{ Model } & \multirow{2}{*}{\multicolumn{2}{|c|}{$\begin{array}{l}\text { Unstandardized } \\
\text { Coefficients }\end{array}$}} & \multirow{2}{*}{$\begin{array}{r}\text { Standardized } \\
\text { Coefficients }\end{array}$} & \multirow{3}{*}{$\mathrm{t}$} & \multirow{3}{*}{ Sig. } & \multicolumn{4}{|c|}{$\%$ Confidence } & \multirow[b]{3}{*}{ part } \\
\hline & & & & & & \multicolumn{2}{|c|}{ Interval for } & \multicolumn{2}{|c|}{ Correlations } & \\
\hline & $\mathrm{B}$ & Std. Error & Beta & & & lower & upper & zero-order & partial & \\
\hline 1 (constant) & 43.323 & 18.331 & - & 2.363 & .021 & 6.827 & 79.818 & - & - & - \\
\hline NI & 1.796 & 1.506 & .168 & 1.193 & .237 & -1.202 & 4.793 & 163 & .134 & .130 \\
\hline MI & .197 & 1.199 & .020 & .164 & .870 & -2.189 & 2.583 & .032 & .019 & .018 \\
\hline LMI & -.600 & 1.328 & -.059 & -.452 & .653 & -3.243 & 2.043 & .016 & -.051 & -.049 \\
\hline EI & 1.201 & 1.406 & .117 & .854 & .396 & -1.598 & 3.999 & .079 & .096 & .093 \\
\hline InterI & -.350 & 1.060 & -.039 & -.330 & .742 & -2.461 & 1.761 & -.033 & -.037 & -.036 \\
\hline BKI & -.754 & 1.178 & -.079 & -.640 & .524 & -3.099 & 1.592 & -.018 & -.072 & -.070 \\
\hline LI & -1.662 & 1.228 & -.191 & -1.353 & .180 & -4.106 & .783 & -.080 & -.151 & -.148 \\
\hline IntraI & 1.638 & 2.031 & .104 & .807 & .422 & -2.405 & 5.682 & .134 & .091 & .088 \\
\hline VSI & .522 & 1.483 & .053 & .352 & .726 & -2.431 & 3.475 & .055 & .040 & .038 \\
\hline
\end{tabular}

Note: NI (Naturalistic Intelligence), MI (Musical Intelligence), LMI (Logical/Mathematical Intelligence), EI (Existential Intelligence), InterI (Interpersonal Intelligence), BKI (Bodily Kinaesthetic Intelligence), LI (Linguistic Intelligence), IntraI (Intrapersonal Intelligence), VSI (Visual/Spatial Intelligence)

Consequently, it can be concluded that there is a positive but not statistically significant relationship between linguistic intelligence and EFL learners' level of L2 vocabulary knowledge. As such, the second null hypothesis would also be confirmed. The result agrees with the findings of the studies conducted by Razmjoo (2008) and Javanmard (2012). In both cases, it was found out that none of the intelligences could predict the learners' language proficiency. By contrast, Skourdi and Rahimi (2010) and Karimi, Pourdana, and Sayyedi (2012), based on the results of their studies, inferred that linguistic intelligence is a better predictor for learning the lexical items of a given foreign language.

To examine the third hypothesis, an Independent-samples T-test was run so as to explore the possible difference between male and female learners' knowledge of vocabulary. Having run a Condescriptive task, the researchers found out that the average mean score of male learners regarding the vocabulary test is substantially greater than that of females $(72.25>61.43)$. As seen in Table 5 , there is also a statistically significant difference between male and female 
learners in terms of their level of L2 lexical knowledge $(\mathrm{t}(88)=2.97, \mathrm{P}=.004<0.05)$. In fact, male EFL learners outperformed females in their vocabulary test. Accordingly, the third null hypothesis would be rejected.

Table5. The results of the independent-samples t-test

\begin{tabular}{|c|c|c|c|c|c|c|c|c|}
\hline & & \multicolumn{2}{|c|}{$\begin{array}{l}\text { Levene's Test for } \\
\text { Equality of Variances }\end{array}$} & \multicolumn{5}{|c|}{ T-test for Equality of Means } \\
\hline & & \multirow[t]{2}{*}{$\mathrm{F}$} & \multirow[t]{2}{*}{ Sig. } & \multirow[t]{2}{*}{$\mathrm{t}$} & \multirow[t]{2}{*}{$\mathrm{df}$} & \multirow[t]{2}{*}{ Sig. (2-tailed) } & \multicolumn{2}{|c|}{$\begin{array}{c}95 \% \text { Confidence interval } \\
\text { of the Difference }\end{array}$} \\
\hline & & & & & & & Lower & Upper \\
\hline \multirow[t]{2}{*}{ Vocab } & $\begin{array}{l}\text { Equal variances } \\
\text { assumed }\end{array}$ & .586 & .446 & 2.977 & 86 & .004 & 3.59146 & 18.03354 \\
\hline & $\begin{array}{l}\text { Equal variances } \\
\text { not assumed }\end{array}$ & & & 2.861 & 38.411 & .007 & 3.16469 & 18.46031 \\
\hline
\end{tabular}

Considering the differences between male and female students in terms of the vocabulary learning process, the results of the present study can be used as evidence supporting the findings of the study conducted by Yan (2009) by virtue of the fact that in both projects there was a statistically significant difference between the genders with respect to their performance on the vocabulary test. However, Yan found out that female EFL learners were superior to their opposite gender. In a similar vein, Wei-Wei (2009), focusing on the reading comprehension skills and gender differences, concluded that most females are global readers and would rather guess the meaning of the words from the context while males are more analytic and utilize bottom-up strategies when reading a text.

Finally, the last hypothesis sought to unravel the possible difference between male and female learners in terms of their MIs scores. A Multivariate Analysis of Variance (MANOVA) was employed to statistically examine the intended difference. Another Condescriptive task was run and it was found out that the average mean scores of males and females for each type of intelligences was not remarkably different. By looking at Table 6, it becomes clear that the difference between the two groups is not statistically significant $(p=0.224>0.05)$.

Table 6. The results of MANOVA comparing the difference between males and females regarding their MIs scores

\begin{tabular}{llcccccc}
\hline \multirow{2}{*}{ Effect } & & & & & & \multicolumn{2}{c}{$\begin{array}{c}\text { Partial Eta } \\
\text { Squared }\end{array}$} \\
\hline Intercept & Pillai's Trace & .989 & 752.307 & 9.000 & 78.000 & .000 & .989 \\
& Wilk's Lambda & .011 & 752.307 & 9.000 & 78.000 & .000 & .989 \\
& Hotelling's Trace & 86.805 & 752.307 & 9.000 & 78.000 & .000 & .989 \\
& Roy's Largest Roo & 86.805 & 752.307 & 9.000 & 78.000 & .000 & .989 \\
\hline Gender & Pillai's Trace & .135 & 1.354 & 9.000 & 78.000 & .224 & .135 \\
& Wilk's Lambda & .865 & 1.354 & 9.000 & 78.000 & .224 & .135 \\
& Hotelling's Trace & .156 & 1.354 & 9.000 & 78.000 & .224 & .135 \\
& Roy's Largest Roo & .156 & 1.354 & 9.000 & 78.000 & .224 & .135 \\
\hline
\end{tabular}

More specifically, except for the linguistic intelligence $(\mathrm{p}=.03<0.05)$ through which female EFL learners performed better on their vocabulary level test, the other types of intelligences were not affected by the gender differences (see Table 7). As such, the forth null hypothesis would be confirmed.

Table7. The effect of gender on each type of intelligences

\begin{tabular}{lccccccc}
\hline Source & $\begin{array}{c}\text { Type of } \\
\text { Intelligence }\end{array}$ & $\begin{array}{c}\text { Type III Sum } \\
\text { of Squares }\end{array}$ & df & Mean Square & F & Sig. & $\begin{array}{c}\text { Partial Eta } \\
\text { Squared }\end{array}$ \\
\hline Gender & NI & 5.900 & 1 & 5.900 & 2.741 & .101 & .031 \\
& MI & 2.988 & 1 & 2.988 & 1.154 & .286 & .013 \\
& LMI & .108 & 1 & .108 & .004 & .835 & .001 \\
& EI & 3.897 & 1 & 3.897 & 1.655 & .202 & .049 \\
& InterI & .004 & 1 & .004 & .001 & .972 & .000 \\
& BKI & 1.458 & 1 & 1.458 & .526 & .470 & .006 \\
& LI & 14.163 & 1 & 14.163 & 4.448 & .038 & .049 \\
& IntraI & .985 & 1 & .985 & .982 & .325 & .011 \\
& VSI & .613 & 1 & .613 & .237 & .628 & .003 \\
\hline
\end{tabular}


This finding is not consistent with what Gogebakan (2003) found out in his study. Providing participants with a pictorial teele inventory for multiple intelligences, he tried to investigate the effect of gender on students' MIs. Interestingly, he came to the conclusion that gender differences were statistically significant in logical/mathematical, bodily kinaesthetic, and musical intelligences scores. In fact, it was observed that the logical and bodily kinaesthetic intelligences average mean scores of male students were higher compared to those of females, whereas the female students enjoyed a higher mean score with respect to the musical intelligence. These findings also support the results of the study conducted by Lin (2009) in which the researcher concluded that self-estimates of males' intelligence types were higher in such domains as mathematical, visual/spatial, and bodily kinaesthetic intelligences. Female learners, on the other hand, surpassed males significantly in terms of verbal/linguistic and musical/rhythmic intelligences.

\section{Conclusion}

Recently, a considerable body of research has been conducted on the application of MIs theory in the foreign language educational settings. Although vocabulary knowledge has largely been considered an important component of language proficiency, few studies have investigated the differential influence of MIs on EFL learners' vocabulary learning process. Many studies conducted in both L1 and L2 (e.g., Read, 2000; Nation, 2001; Qian, 2002) have demonstrated that the students' level of lexical knowledge plays a pivotal role in their reading comprehension abilities as well as the ability to extract new information from the text. Considering these facts, the present study set out to examine the magnitude of the relationship existing between multiple intelligences and male and female Iranian EFL learners' level of L2 lexical knowledge. The results of the study revealed that there was a very small positive correlation between participants' MIs scores and their vocabulary knowledge, which was not statistically significant. Moreover, it was observed that the linguistic intelligence was a better predictor of students' vocabulary knowledge. As such, language teachers should diagnose the students' linguistic intelligence in order to predict the learners' lacks and adopt suitable remedial measures to help learners to overcome their language problems. In this regard, teachers may use such linguistic-oriented activities as storytelling, diary keeping, reading, or formal speech, once they are teaching the lexical items.

Regarding the difference between male and female students in terms of their level of L2 lexical knowledge, the results indicated that there existed a statistically significant difference between the genders. In fact, male learners showed superiority over females in their performances on the vocabulary level test.

\section{References}

Arnold, J., \& Fonseca, M. (2004). Multiple intelligence theory and foreign language learning: A brain-based perspective. International Journal of English Studies, 4(1), 119-136.

Bakic-Miric, N. (2010). Multiple intelligences theory: A milestone innovation in English language teaching at the University of NIS Medical School. Acta Medica Medianae, 49(2), 15-19.

Beglar, D., \& Hunt, A. (2005). Six principles for teaching foreign language vocabulary: A commentary on Laufer, Meara, and Nation's "Ten best ideas". The Language Teacher, 29(7), 7-10.

BemaniNaeini, M., \& Pandian, A. (2010). On the relationship of Multiple Intelligences with listening proficiency and attitudes among Iranian EFL university students. TESL Canada Journal, 28(1), 97- 114.

Christison, M. A. (1999). A Guidebook for Applying Multiple Intelligences Theory in the ESL/EFL Classroom. Burlingame, CA: Alta Book Center.

Crozier, W. R. (1997). Individual Learners: Personality Differences in Education. UK: Routledge

Gardner, H. (1983). Frames of Mind: The Theory of Multiple Intelligences. New York: Basic Books.

Gardner, H. (1999). Intelligence Reframed: Multiple Intelligences for the $21^{\text {st }}$ Century. New York: Basic Books.

Gardner, H (2006). Multiple Intelligences: New Horizons in Theory and Practice. New York: Basic Books.

Göğebakan, D. (2003). How students' multiple intelligences differ in terms of grade level and gender. Unpublished master's thesis, Middle East Technical University, Turkey.

Javanmmard, Y. (2012). On the relationship between multiple intelligences and their performance on vocabulary tests among Iranian EFL learners. Global Journal of Human Social Science, 12(12), 61-73.

Kagan, L. (2000). Multiple Intelligences: Structures and Activities. San Clemente, CA: Kagan Publishing.

Karimi, M., Pourdana, N., \& Sayyedi, R. (2012). A fresh look at testing vocabulary in EFL context: Predictive power of Multiple intelligences. The proceedings of International Conference on Language, Medias, and Culture, IPEDR (pp. 124-125), Singapore.

Kim, I. (2009). The relevance of multiple intelligences to CALL instruction. Reading Matrix: An International Online Journal, 9(1), 1-21.

Lazear, D. (1999). Eight Ways of Teaching: The Artistry of Teaching with Multiple Intelligences. Palatine, IL: IRI Skylight Publishing Inc.

Lefrancois, B. (1991). Detecting over-influential observations in time series. Biometrika, 78 (1), 91-99. 
Lin, S. (2009). Gender and major differences in self-estimates of different aspects of Gardner's multiple intelligences: A study of the undergraduate pre-service teachers in Taiwan. Asian Social Science, 5 (5), 3-14.

Loori, A. A. (2005). Multiple intelligences: A comparative study between the preferences of males and females. Social Behavior and Personality, 33(1), 77-88.

Mahdavi, B. (2007). The role of multiple intelligences in listening proficiency. Unpublished doctoral dissertation, Tehran University, Iran.

McKenzie, W. (1999). Multiple intelligences survey. Retrieved January 9, 2014, from http://surfaquarium.com/MI/MIInvent.htm.

Morgan, J., \& Rinvolucri, M. (2004). Vocabulary (2 ${ }^{\text {nd }}$ Ed.). Oxford: Oxford University Press.

Motallebzadeh, Kh., \& Manouchehri, M. (2009). On the relationship between multiple intelligences and International English Language Testing System (IELTS) reading scores of Iranian learners. Journal of Fundamentals of Mental Health, 11(2), 135-140.

Nation, I. S. P. (2001). Learning Vocabulary in Another Language. Cambridge: Cambridge University Press.

Nelson, M. E. (2006). Mode, meaning, and synaesthesia in multimedia L2 writers. Language Learning and Technology, 10(2), 56-76.

Panahi, A. (2012). From psychology of intelligence to the pedagogy of multiple intelligences: Impact of spatial intelligence-based instruction on the vocabulary performance of EFL learners. The Iranian EFL Journal, 8(2), 128-142.

Pishghadam, R., \& Moafian, F. (2008). The role of Iranian EFL Teachers' multiple Intelligences in their success in language teaching at high schools. Pazhuhesh-e-Zabanha-ye- Khareji, 42, 5-22.

Qian, D. D. (2002). Investigating the relationship between vocabulary knowledge and academic reading performance: An assessment Perspective. Language Learning, 52(3), 513-536.

Razmjoo, S. A. (2008). On the relationship between multiple intelligences and language proficiency. Reading Matrix: An International Online Journal, 8(2), 155-174.

Read, J. (2000). Assessing Vocabulary. Cambridge: Cambridge University Press.

Reis, S. (1998). Work Left Undone. Mansfield Center, CT: Creative Learning Press.

Sharifi, H. (2008). The introductory study of Gardner's multiple intelligence theory in the field of lesson subjects and the students' compatibility. Quarterly Journal of Educational Innovations, 24(10), 10-19.

Skourdi, S., \& Rahimi, A. (2010). The relationship of emotional intelligence and linguistic intelligence in acquiring vocabulary. California Linguistic Notes, 35(1), 2-24.

Tirri, K. (2002). Developing females' talent: Case studies of Finnish Olympians. Journal of Research in Education, $12(1), 80-85$.

Tirri, K., \& Nokelainen, P. (2007). Empirical investigation of the multiple intelligences profiling questionnaire's environmental sensitivity scale. Paper presented at the $12^{\text {th }}$ Biennial Conference of the European Association for Research on Learning and Instruction, Budapest, Hungary.

Wei-Wei, V. (2009). Gender differences in reading comprehension for Chinese secondary school students. Unpublished master's thesis, University of Wisconsin-Platteville, China.

Yan, H. (2009). Empirical study on relations between gender differences and English vocabulary and the overall proficiency level. Asian Social Science, 5(10), 109-114. 